\title{
Model for the economic, energy and environmental evaluation in biomass productions
}

\author{
Marco Fiala, Jacopo Bacenetti \\ Department of Agricultural Engineering, University of Milano, Italy
}

\begin{abstract}
In the near future, renewable energies will have a decisive role to play in attempts to achieve the ambitious objectives fixed by the European Union. Consequently, not only the economic aspect but also energy and environmental issues of agroenergy chains (AEC) must be carefully evaluated. Software $\left(\mathrm{SE}^{3} \mathrm{~A}\right)$ able to assess economic, energy and environmental performance of AEC has been developed. The aim of this paper is to present $\mathrm{SE}^{3} \mathrm{~A}$ and show its usefulness in evaluating different AEC and/or different technical solutions. For the moment, the analysis is restricted to: i) field and ii) post-harvest (transport/storage) phases of the AEC. As an example of $\mathrm{SE}^{3} \mathrm{~A}$ flexibility, economic, energy and environmental costs (EEE costs) related to the cultivation technique used in northern Italy for the poplar short rotation coppice were evaluated.
\end{abstract}

\section{Introduction}

The need to reduce fossil energy consumption and emissions of greenhouse gases (GHG) has led to a huge increase in interest in renewable energy (RE). Considering that the profitability of traditional food crops is falling, RE represents an interesting opportunity for the agricultural sector (Foppa, 2010). The increasing demand for energy, the depletion of fossil fuel stocks and the rise in GHG emissions are problems that are being addressed by many governments and interna-

\footnotetext{
Correspondence: Marco Fiala, Department of Agricultural Engineering, University of Milano, via G. Celoria 2, Milano, 20133, Italy.

Tel. +39.02.50316868. E-mail: marco.fiala@unimi.it

Key words: biomass, energy, chain-supply, sustainability, model, short rotation coppice.

Acknowledgements: our thanks go to the Regione Lombardia and the European Social Fund for financial support in the form of a Post-doctoral Research Fellowship (Progetto Dote Ricerca).

Received for publication: 24 September 2011.

Accepted for publication: 29 February 2012.

(C) Copyright M. Fiala and J. Bacenetti, 2012

Licensee PAGEPress, Italy

Journal of Agricultural Engineering 2012; XLIII:e5

doi:10.4081/jae.2012.e5

This article is distributed under the terms of the Creative Commons Attribution Noncommercial License (by-nc 3.0) which permits any noncommercial use, distribution, and reproduction in any medium, provided the original author(s) and source are credited.
}

tional organizations. Common objectives have already been defined: i) reducing consumption of fossil energy; ii) increasing the share of primary demand through the use of RE; and consequently (iii) the reduction in GHG emissions (European Parliament, 2009, 2010).

The development of agroenergy chains (AEC) is linked to their technical feasibility and the achievement of favorable economic results. The agroenergy sector will not be able to expand without economic sustainability and unless this happens, its contribution to the search for renewable energy sources will be lost. Public subsidies guarantee economic results but run the risk of developing chains that do not have a favorable energy and/or environmental profile. Consequently, AEC global sustainability can be defined through the integration of its economic, energy and environmental performances. The first two aspects are easy to identify by the ratio between returns and costs. The environmental aspect is usually harder to assess and its evaluation can include several items such as air/water pollution, water acidification, toxicity, etc. However, the current approach is focused on GHG emissions only. Given this, an AEC is environmentally acceptable when, while producing energy, it emits less GHG with respect to fossil fuels generating the same energy.

AEC global sustainability (economic, energy and environmental aspects) has been a focus of attention for some time. However, a critical issue remains: the lack of uniformly accepted and applied methodologies. In particular, the calculation of GHG emissions is only a recent development and some aspects are still under discussion (Guinée, 2002; AA.V., 2006; Daviet, 2007; Reap, 2008a, 2008b; Cherubini, 2009). Information about energy and environmental costs is not always reliable and it is often possible to find different results reported for the same AEC. These differences usually come from the use of different methodologies or of non-uniform parameters (Pimentel, 2003; Shapouri, 2003; Farrel, 2006). AEC sustainability cannot be generalized and must be evaluated in its specific context, for example, through on site analysis.

Over the years, many different software programs have been developed to evaluate the energy and environmental aspects related to production processes. The main purpose of these tools is to assess the energy inputs and environmental load associated with the goods produced (ERG, 2006; ARGONNE, 2007; Spugnoli, 2009; Fiala, 2010b; D'Avino, 2010). Nevertheless, these readily-available software programs are generally difficult to apply to AEC because: i) they are not specifically developed to analyze this type of process; ii) they are often complex and difficult for non-experts to use; iii) the whole AEC is rarely analyzed and attention is usually focused only on some phases or operations, neglecting steps that have a big impact on the energyenvironmental costs; iv) they are not flexible enough to assess AECs which are very different among themselves; $v$ ) this is not freeware and expensive licenses frequently have to be bought.

To address these issues, the Department of Agricultural Engineering of the University of Milan has developed a specific software program able to calculate the economic, energy and environmental (EEE) performances of the most widely used AECs. 


\section{Materials and methods}

The $\mathrm{SE}^{3} \mathrm{~A}$ (Software for Economic, Energetic, and Environmental Analysis) software is based on well-known methodologies: i) fixed and variable costs for economic analysis; ii) gross energy requirement (GER) for energy analysis (Slesser, 1982; Franzese, 2009); iii) IPCC and EU guidelines for environmental assessment (ISO, 2006; IPCC, 2006).

The AEC energy and environmental costs are defined with an LCAoriented approach; the software follows the ISO standards related to the Life Cycle Assessment, ISO 14040 (ISO, 2006) according to which fossil fuel consumptions, as well as the GHG emissions related to the production cycle, are considered.

$\mathrm{SE}^{3} \mathrm{~A}$ has the following basic advantages:

- it allows different AECs and/or different technical solutions in the same AEC to be analyzed;

- it is user friendly;

- it provides easy to understand results that allow quick comparisons to be made between different AECs.

At present, the software manages the first two AEC phases: i) the field phase (biomass production and/or supply); and ii) the post-harvest phase (transport/storage/processing). The third and last phase (conversion into energy) is still under development.

For each phase, the operator must identify the logical sequence characterizing the process (single operations list). For all these operations, the amount of utilized production factors, either direct (DF) or indirect (IF), must be specified. According to ISO 14040, the functional unit (FU) is a measure of the performance of the functional outputs of the product system. Materials' and energy flows are related to the selected functional unit, which becomes the reference quantity for every kind of comparison.

Since for the moment assessment is restricted to the first two AEC phases, the possible FUs are:

- the mass (or the volume) of the picked-up (agricultural by-products, animal manure) or produced (energy crop) biomass. In the specific case of biofuels (characterized by different net calorific value, NHV; $\mathrm{MJ} / \mathrm{kg}_{\mathrm{WB}}$ ), the collected energy is the best $\mathrm{FU}$;

- the area of biomass production under assessment.

Once the software is capable of assessing the energy conversion phase it will be possible to select as FU the generated energy (electrical or thermal) or the energy carrier (bioethanol, SVO or biodiesel, biomethane) (Figure 1).

The software requires a huge input of data and information. $\mathrm{SE}^{3} \mathrm{~A}$ can be used for final analysis as well as for first AEC evaluations. In the first case, local and contextualized data, describing in detail the chain under investigation (farm-scale level), are needed. In the second, in which the objective is to achieve general results, input data must be representative of a standard $\mathrm{AEC}$.

As far as the field phase is concerned, the EEE performances are calculated as a function of the soil used for biomass production (AUAENERgr; ha).

The EEE costs of the AEC are expressed by the logical integration of the three following parameters:

- economic costs (も);

- energycosts (MJ);

- environmental costs ( $\mathrm{kg} \mathrm{CO}$ eq.).

The mechanization of field operations is assumed to be carried out first by the farm's machinery fleet or, if this is not possible, by contractors. In this latter case, economic ( $€ / \mathrm{ha})$, energy ( $€ / \mathrm{MJ})$ and environmental ( $\mathrm{kg} \mathrm{CO}$ eq/ha) tariffs must be used as input.

Using farm fleet machines, the EEE costs related to biomass production are computed by also taking into account their possible use over conventional crops (food or feed) cultivated on the farm, dividing all

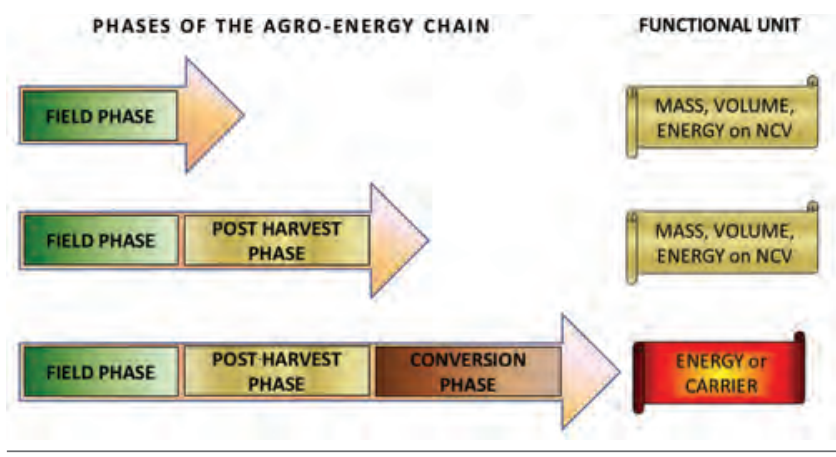

Figure 1. The functional unit choice depends on the chain phases under analysis.

the costs proportionally to their annual use.

The software takes into account the use of DF and IF production factors, although some of them (i.e. land benefit, manpower) are only considered for economic analysis.

The EEE costs linked to DF use are charged exclusively to the energy chain. In fact, they are totally consumed within the AEC and are calculated as:

$$
\begin{array}{ll}
\mathrm{C}_{\mathrm{ECO} D \mathrm{DF}}=\mathrm{M}_{\mathrm{DF}} \cdot \mathrm{P}_{\mathrm{DF}} \cdot \mathrm{AUA}_{\mathrm{ENERGY}} & (€ / \text { year }) \\
\mathrm{C}_{\mathrm{ENE} \_\mathrm{DF}}=\mathrm{M}_{\mathrm{DF}} \cdot \mathrm{EQ}_{\mathrm{DF}} \cdot \mathrm{AUA}_{\mathrm{ENERG}} & (\mathrm{MJ} / \text { year }) \\
\mathrm{C}_{\mathrm{ENV} \_\mathrm{DF}}=\mathrm{M}_{\mathrm{DF}} \cdot \mathrm{FE}_{\mathrm{DF}} \cdot \mathrm{AUA}_{\mathrm{ENERG}} & \left(\mathrm{kg} \mathrm{CO} \mathrm{CO}_{2} \text { eq./year }\right)
\end{array}
$$

where:

$\mathrm{M}_{\mathrm{DF}}=\mathrm{DF}$ amount $\left(\mathrm{kg} / \mathrm{ha} \cdot\right.$ year or $\mathrm{m}^{3} / \mathrm{ha} \cdot$ year $)$;

$\mathrm{P}_{\mathrm{DF}}=\mathrm{DF}$ unit price $\left(€ / \mathrm{kg}\right.$ or $\left.€ / \mathrm{m}^{3}\right)$;

$\mathrm{EQ}_{\mathrm{DF}}=\mathrm{DF}$ energy equivalent ( $\mathrm{MJ} / \mathrm{kg}$ or $\mathrm{MJ} / \mathrm{m}^{3}$ ) (Jarach, 1985);

$\mathrm{FE}_{\mathrm{DF}}=\mathrm{DF}$ emission factor $\left(\mathrm{kg} \mathrm{CO}_{2} \mathrm{eq} / \mathrm{kg}\right.$ or $\left.\mathrm{kg} \mathrm{CO}_{2} \mathrm{eq} / \mathrm{m}^{3}\right)(\mathrm{Bini}, 2002$; Lai, 2004);

$\mathrm{AUA}_{\text {ENERGY }}=$ farm area used for agriculture dedicated to biomass production (ha).

On the contrary, the EEE costs related to the use of indirect production factors (IF) are not charged entirely to the AEC because the factors involved (e.g. machinery, building, etc.) are not completely consumed within a single production cycle. Consequently, the total embedded values $\left(\mathrm{C}_{\mathrm{ECO} \_ \text {_F_tot }} ; \mathrm{C}_{\mathrm{ENE} \_\mathrm{IF} \_t o t} ; \mathrm{C}_{\mathrm{ENV} \_ \text {IF_tot }}\right)$ are as follows:

$$
\begin{aligned}
& \mathrm{C}_{\text {ECO_IF_tot }}=\mathrm{I}_{0} \\
& \mathrm{C}_{\text {ENE_IF_tot }}=\mathrm{M}_{\mathrm{IF}} \cdot \mathrm{EQ}_{\mathrm{IF}} \\
& \mathrm{C}_{\text {ENV_IF_tot }}=\mathrm{M}_{\mathrm{IF}} \cdot \mathrm{FE}_{\mathrm{IF}} \\
& \text { (kg } \mathrm{CO}_{2} \text { eq.) }
\end{aligned}
$$

where:

$\mathrm{I}_{0}=$ investment ( $(\theta)$

$\mathrm{M}_{\mathrm{IF}}=\mathrm{IF}$ amount $\left(\mathrm{kg}\right.$ or $\left.\mathrm{m}^{3}\right)$;

$\mathrm{EQ}_{\mathrm{IF}}=\mathrm{IF}$ energy equivalent $\left(\mathrm{MJ} / \mathrm{kg}\right.$ or $\left.\mathrm{MJ} / \mathrm{m}^{3}\right)(\mathrm{Jarach}, 1985)$;

$\mathrm{FE}_{\mathrm{IF}}=\mathrm{IF}$ emission factor $\left(\mathrm{kg} \mathrm{CO} \mathrm{CO}_{2} \mathrm{eq} / \mathrm{kg}\right.$ or $\left.\mathrm{kg} \mathrm{CO}_{2} \mathrm{eq} / \mathrm{m}^{3}\right)$ (Bini, 2002; Lai, 2004);

On the other hand, because the IF production factors are not completely consumed within a single production cycle, their EEE costs $\left(\mathrm{C}_{\mathrm{ECO} \_\mathrm{F}} ; \mathrm{C}_{\mathrm{ENE} \_\mathrm{F}} ; \mathrm{C}_{\mathrm{ENV} \_\mathrm{F}}\right)$ must be split according to: i) depreciation time ( $D_{E}$; years); ii) total annual use $\left(\mathrm{H}_{\mathrm{T}}\right.$; h/year $)$; iii) annual use for the AEC $\left(\mathrm{H}_{\mathrm{F}} ; \mathrm{h} /\right.$ year $)$ :

$$
\begin{aligned}
& \mathrm{C}_{\text {ECO_IF }}=\left(\mathrm{C}_{\text {ECO_IF_tot }} \cdot \mathrm{H}_{\mathrm{F}}\right) /\left(\mathrm{H}_{\mathrm{T}} \cdot \mathrm{D}_{\mathrm{E}}\right) \\
& \mathrm{C}_{\text {ENE_IF }}=\left(\mathrm{C}_{\text {ENE_IF_tot }} \cdot \mathrm{H}_{\mathrm{F}}\right) /\left(\mathrm{H}_{\mathrm{T}} \cdot \mathrm{D}_{\mathrm{E}}\right) \\
& \mathrm{C}_{\text {ENV_IF }}=\left(\mathrm{C}_{\text {ENV_IF_tot }} \cdot \mathrm{H}_{\mathrm{F}}\right) /\left(\mathrm{H}_{\mathrm{T}} \cdot \mathrm{D}_{\mathrm{E}}\right)
\end{aligned}
$$


The mechanization costs consider the yearly worked area and the effective field capacity of the different machines (FC; ha/h). The software assumes different $\mathrm{FC}$ for the same machine working on the energy crop (AUA ENERGY $_{\text {; }}$ ha) or on conventional crop (AUA $A_{F O O D}$; ha). For farm tractors, the total annual use is computed taking into account, besides operations on energy and conventional crops, other generic jobs (farm road maintenance, cleaning ditches, etc.). Although the RES Directive guidelines do not consider the energy and environmental costs related to IF use, the $\mathrm{SE}^{3} \mathrm{~A}$ can also take into account this option. To calculate the EEE performances, specific records, appropriately developed and organized, are used. These records include technical data about the production factors and can be constantly adopted and updated. The main records refer to: prices, energy equivalents, emission factors and technical parameters of machines, plants and buildings.

In addition to the emissions due to use of production factors, according to the IPCC guidelines that provide default values for this kind of emission, the software also computes emissions of nitrous oxide $\left(\mathrm{E}_{\mathrm{N} 20}\right)$ from the use of nitrogenous fertilizers. This other type of GHG emissions strongly depends on: i) soil and climatic conditions; ii) tillage system; iii) amounts of nitrogenous fertilizers:

$\mathrm{E}_{\mathrm{N} 20}=\mathrm{N}_{\mathrm{R}} \cdot \mathrm{k}_{\mathrm{N} 20} \cdot \mathrm{GWP}_{\mathrm{N} 20} \cdot \mathrm{AUA}_{\mathrm{ENERGY}} \quad\left(\mathrm{kg} \mathrm{CO}_{2}\right.$ eq.year $)$

where:

$\mathrm{N}_{\mathrm{R}}$ = total amount of nitrogen applied to the soil by means of fertilizers, depending on amount and type of fertilizer ( $\mathrm{kg}_{N} / \mathrm{ha} \cdot$ year);

$\mathrm{k}_{\mathrm{N} 20}=$ emission coefficient for nitrogen $\left(\mathrm{kg}_{\mathrm{N} 20} / \mathrm{kg}_{\mathrm{N}}, 0.00125\right)$ (IPCC, 2006);

$\mathrm{GWP}_{\mathrm{N} 20}=$ Global Warming Potential for $\mathrm{N}_{2} \mathrm{O}(-, 296)$ (IPCC, 2006).

The three total AEC costs $\left(\mathrm{C}_{\mathrm{ECO} \_} \mathrm{C} ; \mathrm{C}_{\mathrm{ENE} \_} ; \mathrm{C}_{\mathrm{ENV} \_} \mathrm{C}\right)$ are obtained by adding the costs linked to each production factor used:

$\mathrm{C}_{\mathrm{ECO} \_\mathrm{C}}=\Sigma \mathrm{C}_{\mathrm{ECO} \_\mathrm{DF}}+\Sigma \mathrm{C}_{\mathrm{ECO} \_\mathrm{F}}$

$\mathrm{C}_{\mathrm{ENE} \_\mathrm{C}}=\Sigma \mathrm{C}_{\mathrm{ENE} \_\mathrm{DF}}+\Sigma \mathrm{C}_{\mathrm{ENE} \_\mathrm{IF}}$

$\mathrm{C}_{\mathrm{ENV} \_} \mathrm{C}=\Sigma \mathrm{C}_{\mathrm{ENV} \_D F}+\Sigma \mathrm{C}_{\mathrm{ENV} \_ \text {FF }}+\mathrm{E}_{\mathrm{N} 20}$

(€/year)

(MJ/year)

The EEE costs of the agro-energy chain can be finally represented as a logical addition of these three terms:

$$
\left(\mathrm{C}_{\mathrm{ECO} \_\mathrm{C}}+\mathrm{C}_{\mathrm{ENE} \_\mathrm{C}}+\mathrm{C}_{\mathrm{ENV} \_\mathrm{C}}\right)
$$

When the AEC also produces co-products (or exploitable byproducts), according to the RES Directive, the software allows EEE costs to be allocated on the basis of the energy contents of: i) the main product $(\mathrm{P})$; ii) the co-product (C) or the byproducts (B).

Nevertheless, the EEE costs can also be divided according to: i) P, C or B quantities; ii) their selling price. Therefore, referring to the main product $(\mathrm{P})$, the EEE costs of the AEC ( $\mathrm{C}_{\text {ECO_C_P }}$; $\mathrm{C}_{\text {ENE_C_P }}$; $\left.\mathrm{C}_{\text {ENV_C_P }}\right)$ are expressed as:

$$
\begin{aligned}
& \mathrm{C}_{\text {ECO_C_P }}=\mathrm{C}_{\text {ECO C }} \cdot \mathrm{k}_{\mathrm{A}} \\
& \mathrm{C}_{\text {ENE_C_P }}=\mathrm{C}_{\text {ENE C }} \cdot \mathrm{k}_{\mathrm{A}} \\
& \mathrm{C}_{\text {ENV_C_P }}=\mathrm{C}_{\text {ENV C }} \cdot \mathrm{k}_{\mathrm{A}}
\end{aligned}
$$$$
\text { (€/year) }
$$

(kg CO $\mathrm{CO}_{2}$ eq.year)

where: $k_{A}=$ coefficient of allocation, share of the cost associated with the main product; consequently, $\left(1-\mathrm{k}_{\mathrm{A}}\right)$ is allocated to byproducts (B) or co-products (C); for AEC without exploitable co-products/byproducts, $\mathrm{k}_{\mathrm{A}}=1$.

Starting from absolute costs and taking into account the allocation criterion, specific costs ( $\mathrm{C}_{\text {ECO_C_Ps }} ; \mathrm{C}_{\text {ENE___Ps }} ; \mathrm{C}_{\text {ENv_C_Ps }}$ ) can be calculated according to the FU previously selected. For instance, selecting the wood chip mass $\left(\mathrm{t}_{\mathrm{WB}}\right)$ as FU, we obtain:

$\mathrm{C}_{\mathrm{ECO} \_\mathrm{C} \_ \text {Ps }}=\mathrm{C}_{\mathrm{ECO} \text { C_P }} /\left(\mathrm{Y} \cdot \mathrm{AUA} \mathrm{ANERGY}_{\mathrm{E}}\right)$

$\left(€ / t_{\mathrm{WB}}\right)$
$\mathrm{C}_{\text {ENE_C_Ps }}=\mathrm{C}_{\text {ENE C_- }} \mathrm{p} /\left(\mathrm{Y} \cdot \mathrm{AUA} \mathrm{ANERGY}_{\text {EN }}\right)$

$\left(\mathrm{MJ} / \mathrm{t}_{\mathrm{WB}}\right)$

$\mathrm{CE}_{\mathrm{NV} \_\mathrm{C} \_\mathrm{Ps}}=\mathrm{C}_{\mathrm{ENV} \mathrm{C}_{-} \mathrm{P}} /\left(\mathrm{Y} \cdot \mathrm{AUA}_{\mathrm{ENERGY}}\right)$

$\left(\mathrm{kg} \mathrm{CO} \mathrm{CO}_{2} \mathrm{eq} / \mathrm{t}_{\mathrm{WB}}\right)$

where:

$\mathrm{Y}=$ biomass yield $\left(\mathrm{t}_{\mathrm{WB}} / \mathrm{ha} \cdot\right.$ year $)$.

The specific costs can be also expressed as: i) $€ / \mathrm{t}_{\mathrm{WB}}, \mathrm{MJ} / \mathrm{t}_{\mathrm{WB}}$ and $\mathrm{kg} \mathrm{CO}_{2}$ eq// $\mathrm{twB}_{\mathrm{WB}}$; ii) $€ / \mathrm{MJ}, \mathrm{MJ} / \mathrm{MJ}$ and $\mathrm{kg} \mathrm{CO}_{2}$ eq/MJ; iii) $€ / \mathrm{ha}$, MJ/ha and $\mathrm{kg} \mathrm{CO}$ eq/ha, using as FU the wet biomass, the energy contained in wet biomass, and the area dedicated to biomass production, respectively.

Finally, since sometimes the comparison between different AECs (or technical solutions of the same AEC) does not appear to be immediate, a Global Cost Index (GCI) summarizing the performances achieved on the three aspects is given. The global AEC sustainability is represented by the area of the triangle whose vertices represent the economic, energy and environmental costs. Assuming that the same weight (multi-criteria analysis) is associated with these three aspects, the bigger the triangle area is, the lower the AEC global sustainability is.

The symbols used for the different parameters are shown in Table 1.

\section{A case study}

In Italy, much research has been carried out into poplar short rotation coppice (SRC) and there has appeared to be some variation in results. The performances of this ligneous-biomass crop are strongly affected by: soil and climatic conditions, species, clones and cropping systems (Dubuisson, 1998; Matthews, 2001; Heller, 2003, 2004; Gasol, 2009; Fiala, 2010a; Bacenetti, 2011; Gonzales, 2012).

The case study analyzed here considers the field phase of a poplar SRC. The energy crop is located on an irrigated farm in the Po valley $(\mathrm{AUA}=100 \mathrm{ha}$ ). Part of this total area is dedicated to poplar (AUAENERGY) while the rest is cultivated with maize for silage ( $\left.\mathrm{AUA}_{\mathrm{FOoD}}\right)$.

The basic features of poplar SRC are: i) transplanting system (single row); ii) plant density: 5560 plants/ha ( $0.6 \mathrm{~m}$ on the row; $3.0 \mathrm{~m}$ intrarows); iii) poplar clone: AF2; iv) cutting interval (2 years); v) crop duration (10 years); vi) biomass harvesting system (self-propelled forageharvester equipped with a biomass header) (Fiala, 2011). Two cropping systems are analyzed with and without IF supply (Table 2):

- L: low production factors level, wood-chip yield $\mathrm{Y}=20 \mathrm{t}_{\mathrm{WB}}$ /ha $\cdot$ year (U $=55 \%$ wet basis, LHV $18.5 \mathrm{MJ} / \mathrm{kg}_{\mathrm{DM}}$ );

- $\mathrm{H}$ : high production factors level, wood-chip yield $\mathrm{Y}=35 \mathrm{t}_{\mathrm{WB}} / \mathrm{ha} \cdot$ year ( $\mathrm{U}=55 \%$ wet basis, LHV $\left.18.5 \mathrm{GJ} / \mathrm{t}_{\mathrm{DM}}\right)$.

As far as the two levels of production factors are concerned, the basic differences refer to: i) the mineral fertilizer rate; ii) the pest-control management; and iii) the mechanical weed control.

A schematic presentation of the AEC field phase is shown in Figure 2 , while Table 3 reports the field operations carried out both over poplar SRC and maize.

Poplar transplanting, biomass harvesting and final soil recovery require machines that are not usually part of the farm fleet and are, therefore, carried out by contractors. In this case, from an economic point of view, prices asked by local contractors must be used. Tariffs can be computed with the $\mathrm{SE}^{3} \mathrm{~A}$, running the calculation with a very long annual use of both tractor and machinery.

To facilitate the comparison between different areas in which the poplar SRC can be cultivated, neither the benefit to the land or the general farm management costs have been considered.

Similarly, the economic returns depend only on the sale of wood chip (average market price: $30 € / \mathrm{t}_{\mathrm{WB}}$ ), and ignore possible public subsidies.

\section{An example of computation}

In order to show in detail how the software $\mathrm{SE}^{3} \mathrm{~A}$ works, the energetic and environmental costs of the mineral fertilization operation are analyzed step by step; the case $\mathrm{H}+$ (see Tables 2 and 3) is considered. 
Table 1. Symbols used in the description of methods.

\begin{tabular}{|c|c|c|}
\hline Symbol & Parameter & Unit of measurement \\
\hline LHV & Biomass low heat value & $\mathrm{MJ} / \mathrm{kg}_{\mathrm{DM}}$ \\
\hline NHV & Biomass net heat value & $\mathrm{MJ} / \mathrm{kg}_{\mathrm{WB}}$ \\
\hline $\mathrm{U}$ & Biomass moisture content & $\%$ wet basis \\
\hline Y & Biomass yield & $t_{\mathrm{wB}} / \mathrm{ha} / \mathrm{year}$ \\
\hline $\begin{array}{l}\text { AUA } \\
\text { AUA }_{\text {ENERGY }} \\
\text { AUA }_{\text {FOOD }}\end{array}$ & $\begin{array}{l}\text { Total farm agricultural used area } \\
\text { Farm agricultural used area addressed to energy crop } \\
\text { Farm agricultural used area to conventional crop }\end{array}$ & ha \\
\hline $\begin{array}{l}\text { CECO_DF }_{\text {ENE_DF }} \\
\text { C }_{\text {ENV_DF }}\end{array}$ & EEE costs related to the DF & $\begin{array}{c}\text { Єlyear } \\
\text { MJ/year } \\
\mathrm{kg} \mathrm{CO} \text { eq.year }\end{array}$ \\
\hline $\mathrm{M}_{\mathrm{DF}}$ & DF amount & $\mathrm{kg}$ or m³/ha/year \\
\hline $\mathrm{P}_{\mathrm{DF}}$ & DF unit price & $€ \mathrm{~kg}$ or $€ / \mathrm{m}^{3}$ \\
\hline $\mathrm{EQ}_{\mathrm{DF}}$ & DF energy equivalent & $\mathrm{MJ} / \mathrm{kg}$ or $\mathrm{MJ} / \mathrm{m}^{3}$ \\
\hline $\mathrm{FE}_{\mathrm{DF}}$ & DF emission factor & $\mathrm{kg} \mathrm{CO}{ }_{2} \mathrm{eq} / \mathrm{kg}$ or kg $\mathrm{CO}_{2} \mathrm{eq} / \mathrm{m}^{3}$ \\
\hline $\begin{array}{l}\text { CECO_IF_tot }_{\text {ENE_IF_tot }} \\
\text { C }_{\text {ENE }} \\
\text { CENV_IF_tot }\end{array}$ & EEE total embedded value related to the IF & $\begin{array}{c}€ \\
\mathrm{MJ} \\
\mathrm{kg} \mathrm{CO} \text { eq. }\end{array}$ \\
\hline $\begin{array}{l}\text { CECO_IF } \\
\mathrm{C}_{\text {ENE_IF }} \\
\mathrm{C}_{\text {ENV_IF }} \\
\end{array}$ & EEE costs related to the IF & $\begin{array}{c}€ \text { yyear } \\
\text { MJ/year } \\
\mathrm{kg} \mathrm{CO} \text { eq./year }\end{array}$ \\
\hline $\mathrm{I}_{0}$ & Investment & $€$ \\
\hline $\mathrm{M}_{\mathrm{IF}}$ & IF amount & $\mathrm{kg}$ or $\mathrm{m}^{3}$ \\
\hline $\mathrm{EQ}_{\mathrm{IF}}$ & IF energy equivalent & $\mathrm{MJ} / \mathrm{kg}$ or $\mathrm{MJ} / \mathrm{m}^{3}$ \\
\hline $\mathrm{FE}_{\mathrm{IF}}$ & IF emission factor & $\mathrm{kg} \mathrm{CO}{ }_{2} \mathrm{eq} / \mathrm{kg}$ or $\mathrm{kg} \mathrm{CO}_{2} \mathrm{eq} / \mathrm{m}^{3}$ \\
\hline $\mathrm{D}_{\mathrm{E}}$ & Depreciation time (tractors and machinery) & years \\
\hline $\mathrm{H}_{\mathrm{T}}$ & Total annual use (tractors and machinery) & h/year \\
\hline $\mathrm{H}_{\mathrm{F}}$ & Annual use over AEC (machinery) & $\mathrm{h} /$ year \\
\hline $\mathrm{FC}$ & Effective field capacity (machinery) & ha/h \\
\hline $\mathrm{E}_{\mathrm{N} 20}$ & GHG emissions related to nitrogenous fertilizers & $\mathrm{kg} \mathrm{CO}$ eq./ha/year \\
\hline $\mathrm{N}_{\mathrm{R}}$ & Nitrogen applied to the soil by fertilizers & $\mathrm{kg}_{N} /$ ha/year \\
\hline $\mathrm{k}_{\mathrm{N} 20}$ & Nitrogen emission coefficient & $\mathrm{kg}_{\mathrm{N} 2} / \mathrm{kgN}$ \\
\hline $\begin{array}{l}\mathrm{C}_{\text {ECO_C }} \\
\mathrm{C}_{\text {ENE_C }} \\
\mathrm{C}_{\text {ENV_C }} \\
\mathrm{C}_{\text {EEE_C }}\end{array}$ & $\begin{array}{l}\text { AEC economic costs } \\
\text { AEC energy costs } \\
\text { AEC environmental costs } \\
\text { EEE costs of the AEC }\end{array}$ & $\begin{array}{c}€ \text { year } \\
\text { MJ/year } \\
\mathrm{kg} \mathrm{CO} \text { eq.year } \\
\text { - }\end{array}$ \\
\hline $\begin{array}{l}\text { CECO_CP } \\
C_{\text {ENE_C_P }} \\
C_{\text {ENV_C_P }}\end{array}$ & $\begin{array}{l}\text { AEC economic costs allocated on main } P \\
\text { AEC energy costs allocated on main } P \\
\text { AEC environmental costs allocated on main } P\end{array}$ & $\begin{array}{c}€ / \mathrm{FU} \\
\mathrm{MJ} / \mathrm{FU} \\
\mathrm{kg} \mathrm{CO} \text { eq./FU }\end{array}$ \\
\hline $\mathrm{k}_{\mathrm{A}}$ & Coefficient of allocation & $\%$ \\
\hline $\begin{array}{l}\mathrm{C}_{\text {ECO_C_Ps }} \\
\mathrm{C}_{\text {ENE_C_Ps }} \\
\text { CENV__PPs }_{\text {EN }}\end{array}$ & $\begin{array}{l}\text { AEC specific economic costs, related to FU } \\
\text { AEC specific energy costs, related to FU } \\
\text { AEC specific environmental costs, related to FU }\end{array}$ & $\begin{array}{c}€ / \mathrm{FU} \\
\mathrm{MJ} / \mathrm{FU} \\
\mathrm{kg} \mathrm{CO} 2 \mathrm{eq} / \mathrm{FU}\end{array}$ \\
\hline$\eta_{\mathrm{g}}$ & Tractor power coupling efficiency & $\%$ \\
\hline $\mathrm{P}_{\mathrm{M}}$ & Tractor maximum power & $\mathrm{kW}$ \\
\hline$P_{R}$ & Power required by coupled machine & $\mathrm{kW}$ \\
\hline
\end{tabular}

Table 2. General pattern of the economic, energy and environmental cost analysis.

\begin{tabular}{lll} 
Cropping system & Cases \\
$\mathrm{L}$ & Yes & $\mathrm{L}+$ \\
& No & $\mathrm{L}-$ \\
$\mathrm{H}$ & Yes & $\mathrm{H}+$ \\
& No & $\mathrm{H}-$ \\
\hline
\end{tabular}




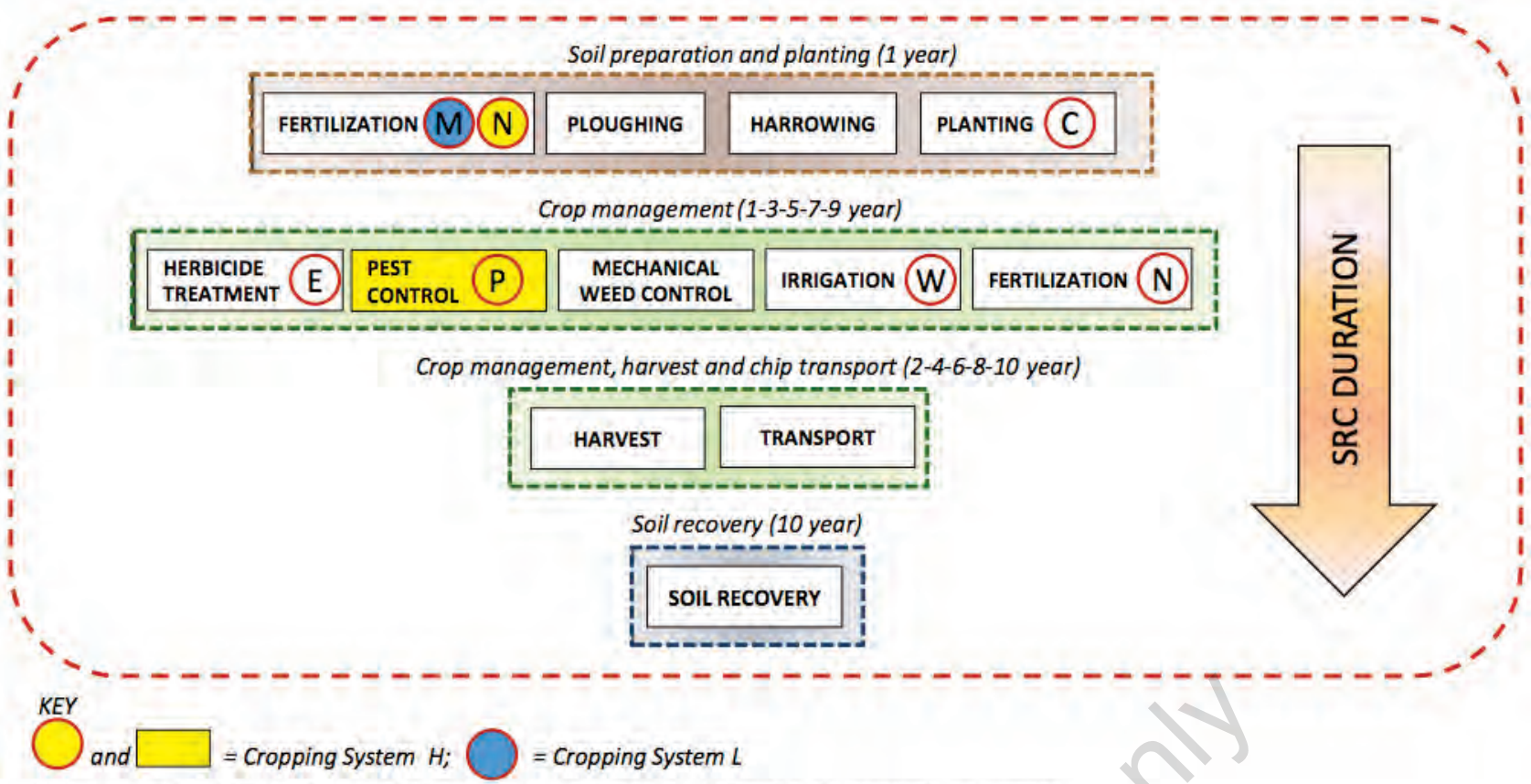

$M=$ manure, $N=$ nitrogen mineral fertilization, $C=$ cuttings, $E=$ herbicide,$P=$ pesticide, $W=$ water

Figure 2. Field phase of the poplar short rotation coppice agroenergy chain: the two cropping systems.

Table 3. Inventory of two cropping systems.

\begin{tabular}{|c|c|c|c|c|c|c|c|c|c|}
\hline & Operation & $\operatorname{CS}(*)$ & Mechanization & & & & (No & ear & Notes \\
\hline & & & $\begin{array}{c}\text { Machinery } \\
\mathrm{FC}(\mathrm{ha} / \mathrm{h}) ; \mathrm{P}_{\mathrm{R}}(\mathrm{kW})\end{array}$ & $\begin{array}{l}\text { Tractor } \\
\mathbf{P}_{M}(k W)\end{array}$ & Owner & $\begin{array}{l}\text { Coupling } \\
\text { and size }\left({ }^{\circ}\right)\end{array}$ & Poplar & Maize & \\
\hline Pre-planting & $\begin{array}{l}\text { Pre-planting } \\
\text { fertilization }\end{array}$ & $\mathrm{H}$ & $\begin{array}{c}\text { Fertilizer spreader } \\
3.0 ; 55\end{array}$ & 90 & & $\begin{array}{c}\mathrm{PP}, \\
1500 \mathrm{dm}^{3}\end{array}$ & $\begin{array}{c}1 \\
(1)\end{array}$ & - & $\begin{array}{c}150 \mathrm{~kg} \mathrm{~N}, 120 \mathrm{~kg} \mathrm{P}_{2} \mathrm{O}_{5} \\
250 \mathrm{~kg} \mathrm{~K} \mathrm{O} / \mathrm{ha}\end{array}$ \\
\hline & & $\mathrm{L}$ & $\begin{array}{c}\text { Manure spreader } \\
2.0 ; 40\end{array}$ & & mer & $\begin{array}{l}\text { TP, } 10 \mathrm{t} \\
10 \mathrm{~m}^{3}\end{array}$ & $\begin{array}{c}1 \\
1 \\
(1)\end{array}$ & $\begin{array}{l}\text { From } 1 \text { to } 10 \\
\text { (1) }\end{array}$ & 50 tha manure \\
\hline & $\begin{array}{l}\text { Primary } \\
\text { soil cultivation }\end{array}$ & $\mathrm{H} ; \mathrm{L}$ & $\begin{array}{l}\text { Plough } \\
0.6 ; 85\end{array}$ & 190 & Farmer & $\begin{array}{c}\text { P, } \\
\text { double shovel }\end{array}$ & $\begin{array}{c}1 \\
(1)\end{array}$ & $\begin{array}{l}\text { From } 1 \text { to } 10 \\
\text { (1) }\end{array}$ & - \\
\hline & $\begin{array}{l}\text { Secondary soil } \\
\text { cultivation }\end{array}$ & $\mathrm{H} ; \mathrm{L}$ & $\begin{array}{c}\text { Rotary harrow } \\
0.5 ; 55\end{array}$ & 90 & Farmer & $\begin{array}{l}\mathrm{PP} \\
2.40 \mathrm{~m}\end{array}$ & $\begin{array}{c}1 \\
(1)\end{array}$ & $\begin{array}{l}\text { From } 1 \text { to } 10 \\
\text { (1) }\end{array}$ & 5560 cuttings/ha \\
\hline Planting & Planting & $\mathrm{H} ; \mathrm{L}$ & $\begin{array}{c}\text { Planting machine } \\
0.7 ; 65\end{array}$ & 100 & Contractors & $\begin{array}{c}\text { T, } \\
\text { double row }\end{array}$ & $\begin{array}{c}1 \\
(1)\end{array}$ & - & \\
\hline Crop management & $\begin{array}{l}\text { Chemical weed } \\
\text { control }\end{array}$ & & $\begin{array}{c}\text { Spraying machine } \\
\text { 3.0;40 }\end{array}$ & 90 & Farmer & $\begin{array}{l}\text { PP, } 15 \mathrm{~m}, \\
1000 \mathrm{dm}^{3}\end{array}$ & $\begin{array}{l}1-3-5-7-9 \\
\quad(1)\end{array}$ & $\begin{array}{l}\text { From } 1 \text { to } 10 \\
\text { (1) }\end{array}$ & $20 \mathrm{~kg} / \mathrm{ha}$ \\
\hline & Pest control & & $\begin{array}{c}\text { Spraying machine } \\
\text { 3.0; } 40\end{array}$ & 90 & Farmer & $\begin{array}{l}\text { PP, } 15 \mathrm{~m}, \\
1000 \mathrm{dm}^{3}\end{array}$ & $\begin{array}{c}1-3-5-7-9 \\
\text { (1) }\end{array}$ & $\begin{array}{l}\text { From } 1 \text { to } 10 \\
\text { (1) }\end{array}$ & $10 \mathrm{~kg} / \mathrm{ha}$ \\
\hline & & $\mathrm{L}$ & $\begin{array}{c}\text { Spraying machine } \\
3.0 ; 40\end{array}$ & - & Farmer & $\begin{array}{l}\text { PP, } 15 \mathrm{~m}, \\
1000 \mathrm{dm}^{3}\end{array}$ & - & $\begin{array}{l}\text { From } 1 \text { to } 10 \\
\text { (1) }\end{array}$ & - \\
\hline & Cover fertilization & $\mathrm{H}$ & $\begin{array}{c}\text { Fertilizer spreader } \\
3.0 ; 55\end{array}$ & 90 & Farmer & $\begin{array}{c}\mathrm{PP}, \\
1500 \mathrm{dm}^{3}\end{array}$ & $\begin{array}{l}3-5-7-9 \\
(1)\end{array}$ & $\begin{array}{l}\text { From } 1 \text { to } 10 \\
\text { (2) }\end{array}$ & $\mathrm{H}=320 \mathrm{~kg} / \mathrm{ha}$ (urea) \\
\hline & & $\mathrm{L}$ & $\begin{array}{c}\text { Fertilizer spreader } \\
3.0 ; 55\end{array}$ & 90 & Farmer & $\begin{array}{c}\text { PP, } \\
1500 \mathrm{dm}^{3}\end{array}$ & $\begin{array}{l}3-5-7-9 \\
(1)\end{array}$ & $\begin{array}{l}\text { From } 1 \text { to } 10 \\
\text { (2) }\end{array}$ & $\mathrm{L}=200 \mathrm{~kg} / \mathrm{ha}$ (urea) \\
\hline & $\begin{array}{l}\text { Mechanical weed } \\
\text { control }\end{array}$ & $\mathrm{H}$ & $\begin{array}{l}\text { Rotary harrow } \\
\text { 0.5; } 55\end{array}$ & 90 & Farmer & $\begin{array}{c}\mathrm{PP} \\
2.40 \mathrm{~m}\end{array}$ & $\begin{array}{l}1-3-5-7-9 \\
(2)\end{array}$ & - & - \\
\hline & & $\mathrm{L}$ & Rotary harrow & $\begin{array}{c}90 \\
0.5 ; 55\end{array}$ & Farmer & PP, & $\begin{array}{l}1-3-5-7-9 \\
2.40 \mathrm{~m}\end{array}$ & $\begin{array}{c}- \\
(1)\end{array}$ & - \\
\hline Harvest & & $\mathrm{H} ; \mathrm{L}$ & $\begin{array}{c}\text { Harvester } \\
\text { 1.0; - }\end{array}$ & - & Contractors & SPM & $\begin{array}{c}2-4-6-8-10 \\
(1)\end{array}$ & - & $\begin{array}{l}\mathrm{H}=35 \mathrm{t}_{\mathrm{WB}} / \text { ha year } \\
\mathrm{L}=20 \mathrm{t}_{\mathrm{WB}} \text { /ha year }\end{array}$ \\
\hline & Transport & $\mathrm{H} ; \mathrm{L}$ & $\begin{array}{c}\text { n.3 Trailer } \\
0.33 ; 30\end{array}$ & 90 & $\begin{array}{l}\text { Contractors, } \\
\text { farmer }\end{array}$ & T, PP & $\begin{array}{l}2-4-6-8-10 \\
\text { (1) }\end{array}$ & - & $\begin{array}{l}\mathrm{H}=35 \mathrm{t}_{\mathrm{wB}} \text { /ha year } \\
\mathrm{L}=20 \mathrm{twB}_{\mathrm{wB}} \text { /ha year }\end{array}$ \\
\hline Final recovery & Soil recovery & $\mathrm{H} ; \mathrm{L}$ & Hoeing machine & 90 & Contractors & $\mathrm{P}$ & 10 & - & - \\
\hline & & & & & & & (I) & - & - \\
\hline
\end{tabular}

${ }^{*} \mathrm{CS}$, cropping system; ${ }^{\circ P}$, coupling with pto $\left(\eta_{\mathrm{s}}=0.7\right) ;$; coupling without pto $\left(\eta_{\mathrm{s}}=0.65\right)$; T, trailed coupling $\left(\eta_{\mathrm{g}}=0.56\right)$; SPM, self-propelled machine. 
Economic costs computation are not reported, taking into account that the methodology (Lazzari, 2005) is well known.

Energy and environmental costs due to direct production factor

Energy and environmental costs depend on nitrogenous fertilizers, fuel and oil consumption. The amount of fertilizer is input data provided by the user while both fuel and oil consumptions are calculated by the software according to: i) required power by the machine $\left(\mathrm{P}_{\mathrm{R}}, \mathrm{kW}\right)$; ii) maximum power of tractor $\left(\mathrm{P}_{\mathrm{M}}, \mathrm{kW}\right)$; iii) type of coupling (coupling efficiency; $\eta_{\mathrm{g}}$ ); iv) minimum specific fuel consumption equal to 220 $\mathrm{g} / \mathrm{kWh}$. Given reports in the literature (Jarach, 1985; Bini, 2002; Lai, 2004; Saunders, 2006):

- $\mathrm{M}_{\mathrm{DF} \_1, \mathrm{MDF} \_2}, \mathrm{M}_{\mathrm{DF} \_3}=$ amounts of nitrogenous fertilizers (urea, $46 \% \mathrm{~N}$ ), fuel and oil, respectively equal to $80,4.05$ and $0.02 \mathrm{~kg} / \mathrm{ha} \cdot$ year;

- $\mathrm{EQ}_{\mathrm{DF} \_1}, \mathrm{EQ}_{\mathrm{DF} \_2}, \mathrm{EQ}_{\mathrm{DF} \_3}=$ energy equivalents for nitrogenous fertilizers, fuel and oil, respectively equal to $33.8,51.3$ and $82.0 \mathrm{MJ} / \mathrm{kg}$;

- $\mathrm{FE}_{\mathrm{DF}_{-} 1}, \mathrm{FE}_{\mathrm{DF} \_2}, \mathrm{FE}_{\mathrm{DF} \_3}=$ emission factors, respectively equal to 4.80 , 3.64 and $3.46 \mathrm{~kg} \mathrm{CO}{ }_{2} \mathrm{eq} / \mathrm{kg}$; bearing in mind (1b) and substituting, the direct energy costs are:

$\mathrm{C}_{\text {ENE_DF_1 }}=(80 \cdot 33.8) \cdot 40 \cong 108,160 \mathrm{MJ} /$ year for urea;

$\mathrm{C}_{\text {ENE_DF_2 }}=(4.05 \cdot 51.3) \cdot 40 \cong 8311 \mathrm{MJ} /$ year for fuel;

$\mathrm{C}_{\text {ENE_DF_3 }}=(0.02 \cdot 82.0) \cdot 40 \cong 66 \mathrm{MJ} /$ year for lubricant;

for a total of:

$\mathrm{C}_{\text {ENE_DF_FERT }}=\mathrm{C}_{\text {ENE_DF_1 }}+\mathrm{C}_{\text {ENE_DF_2 }}+\mathrm{C}_{\text {ENE_DF_3 }}=116,537 \mathrm{MJ} / \mathrm{year}$.

Then, considering (equation 1c) and substituting, the direct environmental costs are:

$\mathrm{C}_{\text {ENv_DF_1 }}=(80 \cdot 4.80) \cdot 40 \cong 15,360 \mathrm{~kg} \mathrm{CO} \mathrm{CO}_{2} \mathrm{eq} /$ year for fertilizers;

$\mathrm{C}_{\text {ENv_DF_2 }}=(4.05 \cdot 3.64) \cdot 40 \cong 590 \mathrm{~kg} \mathrm{CO} 2 \mathrm{eq}$. year for fuel;

$\mathrm{C}_{\text {ENV_DF_3 }}=(0.02 \cdot 3.46) \cdot 40 \cong 3 \mathrm{~kg} \mathrm{CO} \mathrm{CO}_{2} \mathrm{eq}$ /year for lubricant.

Now considering: i) to distribute urea $(46 \% \mathrm{~N})$; ii) an emission coefficient for nitrogen $\mathrm{k}_{\mathrm{N} 20}=0.00125$; and iii) a $\mathrm{GWP}_{\mathrm{N} 20}=296$, the GHG emissions linked to nitrous oxide emission from the soil are (equation 4):

$$
\mathrm{E}_{\mathrm{N} 20}=(80 \cdot 0.46) \cdot 0.00125 \cdot 296 \cdot 40 \cong 5446 \mathrm{~kg} \mathrm{CO} \text { eq.year }
$$

for a total of:

$\mathrm{C}_{\mathrm{ENV} \_\mathrm{DF} \_ \text {FERT }}=\mathrm{C}_{\mathrm{ENV} \_ \text {DF_1 }}+\mathrm{C}_{\mathrm{ENV} \_ \text {DF_2 } 2}+\mathrm{C}_{\text {ENv_DF_3 }} \mathrm{E}_{\mathrm{N} 20} \cong 21,400 \mathrm{~kg} \mathrm{CO}_{2} \mathrm{eq} /$ year

Energy and environmental costs due to indirect production factor

Similarly to DF costs, and considering reports in the literature (Jarach, 1985; Fiala, 2011):

- $\mathrm{M}_{\mathrm{IF}}=$ spreader and tractor masses, equal to 350 and $5050 \mathrm{~kg}$, respectively;

- $\mathrm{EQ}_{\mathrm{IF}}=$ spreader and tractor energy equivalents, equal ${ }^{1}$ to 69.0 and $92.0 \mathrm{MJ} / \mathrm{kg}$, respectively;

- $\mathrm{FE}_{\mathrm{IF}}=$ spreader and tractor factor emission, respectively equal to 11.0 and $14.7 \mathrm{~kg} \mathrm{CO}{ }_{2} \mathrm{eq} / \mathrm{kg}$, respectively;

- $\mathrm{D}_{\mathrm{E}}=$ spreader and tractor depreciation time, equal to 8 and 12 years, respectively; the embedded energy costs both in fertilizer spreader and coupled tractors are computed (equations $2 \mathrm{~b}$ and $\mathrm{c}$ ) as:

$\mathrm{C}_{\text {ENE_IF_totl }}=350 \cdot 69.0=24,150 \mathrm{MJ}$ for spreader;

$\mathrm{C}_{\text {ENE IF_tot2 }}=5050 \cdot 92.0=464,600 \mathrm{MJ}$ for tractor;

$\mathrm{C}_{\text {ENV_IF_totl }}=350 \cdot 11.0=3850 \mathrm{~kg} \mathrm{CO} 2$ eq. for spreader;

$\mathrm{C}_{\text {EN__IF_tot2 }}=5050 \cdot 14.7=74,235 \mathrm{~kg} \mathrm{CO} \mathrm{CO}_{2}$ eq. for tractor.

${ }^{1}$ All the embedded energy is assumed as electrical energy (Fiorense, 2007); consequently, the $F E_{\text {IF }}$ is calculated on the basis of $0.575 \mathrm{~kg} \mathrm{CO}_{2} \mathrm{eq} . / \mathrm{kWh}$ (average $\mathrm{CO}_{2}$ emission for Italian electrical system).
These embedded energies and GHG must be divided according to the annual use of the two machines over the poplar SRC and maize areas. For instance, taking an $\mathrm{AUA}_{\mathrm{ENERGY}}=40$ ha and a $\mathrm{FC}=3.0 \mathrm{ha} / \mathrm{h}$ (see Table 3), considering one distribution per year over poplar SRC and two distributions per year over maize, the total annual use of the spreader is $\mathrm{HT}_{1}=13.3+40.0=53.3 \mathrm{~h} /$ year.

Supposing that the coupled tractor is used on the farm for a total time of $\mathrm{H}_{\mathrm{T} 2}=800 \mathrm{~h} / \mathrm{year}$, the embedded energy chargeable to mineral fertilization for the whole poplar cycle is (equations $3 b$ and $c$ ):

$\mathrm{C}_{\text {ENE_IF_1 }}=[(24,150 \cdot 13.3) /(53.3 \cdot 8)] \cong 753 \mathrm{MJ} /$ year for spreader;

$\mathrm{C}_{\text {ENE_IF_2 }}=[(464,600 \cdot 13.3) /(800 \cdot 12)] \cong 644 \mathrm{MJ} /$ year for tractor;

$\mathrm{C}_{\text {ENV_IF_1 }}=[(3850 \cdot 13.3) /(53.3 \cdot 8)] \cong 120 \mathrm{~kg} \mathrm{CO} \mathrm{CO}_{2} \mathrm{eq} /$ year for spreader;

$\mathrm{C}_{\text {ENV_IF_2 }}=[(74,235 \cdot 13.3) /(800 \cdot 12)] \cong 103 \mathrm{~kg} \mathrm{CO}$ eq./year for tractor;

for a total of:

$\mathrm{C}_{\text {ENE_IF_FERT }}=\mathrm{C}_{\text {ENE_IF_1 }}+\mathrm{C}_{\text {ENE_IF_2 }}=1397 \mathrm{MJ} / \mathrm{year}$.

$\mathrm{C}_{\text {ENV_IF_FERT }}=\mathrm{C}_{\text {ENV_IF_1 }}+\mathrm{C}_{\text {ENV_IF_2 }}=223 \mathrm{~kg} \mathrm{CO}_{2} \mathrm{eq}$. year.

Total energy and environmental costs related to the mineral fertilization carried out during the whole poplar cycle is given by the sum of the above costs (equations $5 \mathrm{~b}$ and $\mathrm{c}$ ):

$\mathrm{C}_{\text {ENE_FERT }}=\mathrm{C}_{\text {ENE_DF_FERT }}+\mathrm{C}_{\text {ENE_IF_FERT }}=117,936 \mathrm{MJ} /$ year.

$\mathrm{C}_{\mathrm{ENV} \_ \text {FERT }}=\mathrm{C}_{\mathrm{ENV} \_\mathrm{DF} \_ \text {FERT }}+\mathrm{C}_{\mathrm{ENV} \_ \text {IF_FERT }}=21,623 \mathrm{~kg} \mathrm{CO}_{2} \mathrm{eq}$. $y$ year.

Since byproducts are not present, the coefficient of allocation is $\mathrm{k}_{\mathrm{A}}=$ 1 and the entire energy and environmental costs can be allocated (equations $8 \mathrm{~b}$ and $\mathrm{c}$ ) to wood chip mass (i.e. $\mathrm{Y} \cdot \mathrm{AUA}_{\mathrm{ENERGY}}=1400 \mathrm{t}_{\mathrm{WB}}$ ):

$\mathrm{C}_{\text {ENE_Ps_FERT }}=117,936 / 1400=84.2 \mathrm{MJ} / \mathrm{t}_{\mathrm{WB}}$.

$\mathrm{C}_{\text {ENV_Ps_FERT }}=21,623 / 1400=15.4 \mathrm{~kg} \mathrm{CO} \mathrm{CO}_{2} \mathrm{eq} / \mathrm{t}_{\mathrm{WB}}$.

\section{Results}

Taking wood chip production ( $\mathrm{t}_{\mathrm{DM}}$ ) as functional unit, the specific economic, energy and environmental costs are reported in Table 4 and Figure 3. Their trend clearly shows that under the case study conditions (basically characterized for the operations of planting, harvest and soil recovery made by contractors):

- the EEE costs are substantially independent of $A U A_{\text {ENERGY }}$ for both the adopted cropping systems ( $\mathrm{H}$ and $\mathrm{L})$;

- the best performances are always achieved in an $\mathrm{H}$ cropping system (related to a high biomass production). On average, passing from the $\mathrm{H}$ to the $\mathrm{L}$ system, the $30 \%$ increase in EEE costs is due to the fact that the low level of production factors gives a smaller biomass yield;

- the indirect production factors result in an increase in specific energy and environmental costs, for both L and H poplar SRC cropping systems.

In more detail, by increasing the farm AUA ${ }_{\text {ENERGY }}$ from 5 to 95 hectares, all the specific costs show a slight decrease:

- economic cost: i) -1.9\% for the $\mathrm{H}$ cropping system (range 36.2-35.4 $€ / \mathrm{t}_{\mathrm{DM}}$ ); ii) $-2.2 \%$ for the $\mathrm{L}$ cropping system (range 48.0-47.1 $€ / \mathrm{t}_{\mathrm{DM}}$ ); energy cost: i) $-1.6 \%$ for the $\mathrm{H}$ cropping system (range 792-779 $\mathrm{MJ} / \mathrm{t}_{\mathrm{DM}}$, equal to $4.3-4.2 \%$ of the wood chip LHV); ii) $-1.9 \%$ (range $1053-1033 \mathrm{MJ} / \mathrm{t}_{\mathrm{DM}}$, equal to $5.7-5.5 \%$ of the wood chip LHV) for the L cropping system;

- environmental cost: i) $-2.0 \%$ (range 105.9-108.1 $\mathrm{kg} \mathrm{CO}_{2} \mathrm{eq} / \mathrm{t}_{\mathrm{DM}}$ ) for the $\mathrm{H}$ cropping system; ii) $-2.3 \%$ (range $137.7-1346 \mathrm{~kg} \mathrm{CO}$ eq/ $\mathrm{t}_{\mathrm{DM}}$ ). Considering now the influence of the indirect production factors 
Table 4. Specific economic, energy and environmental costs and global costs index for the 4 considered cases.

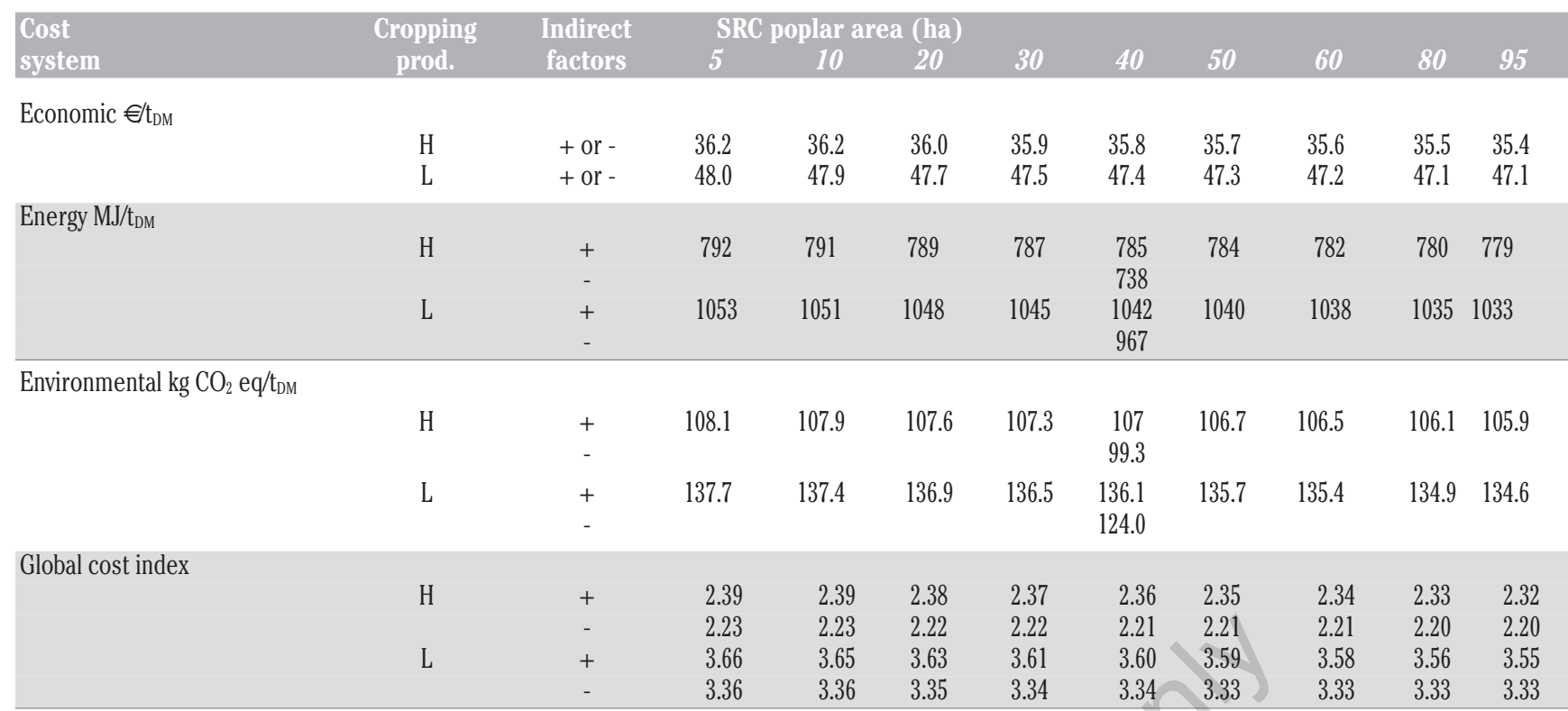

SRC, short rotation coppice.
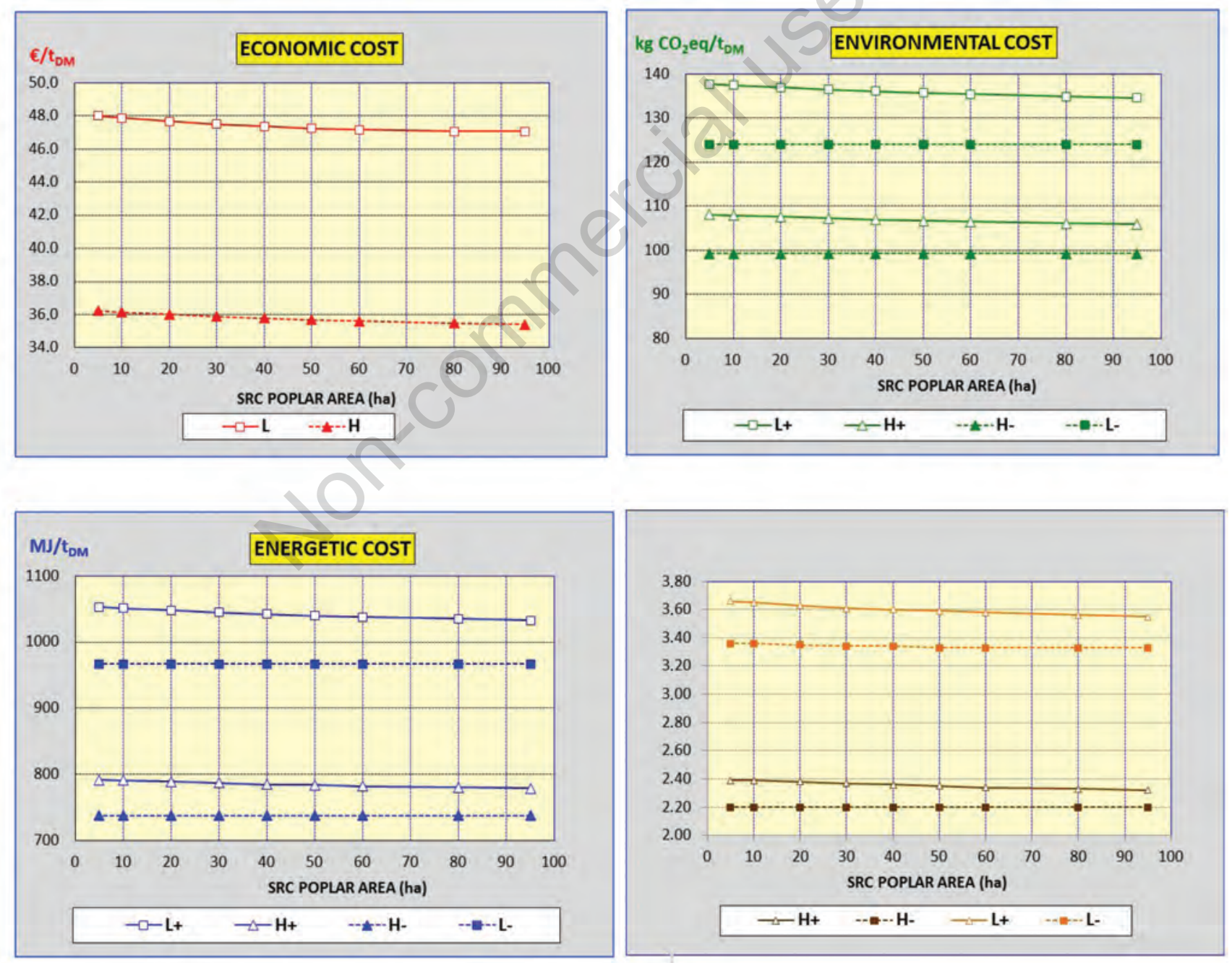

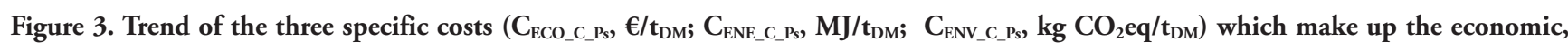
energy and environmental costs and corresponding trend of the global costs index (GCI) $v$ s the farm area assigned to poplar short rotation coppice (SRC). (AUA 

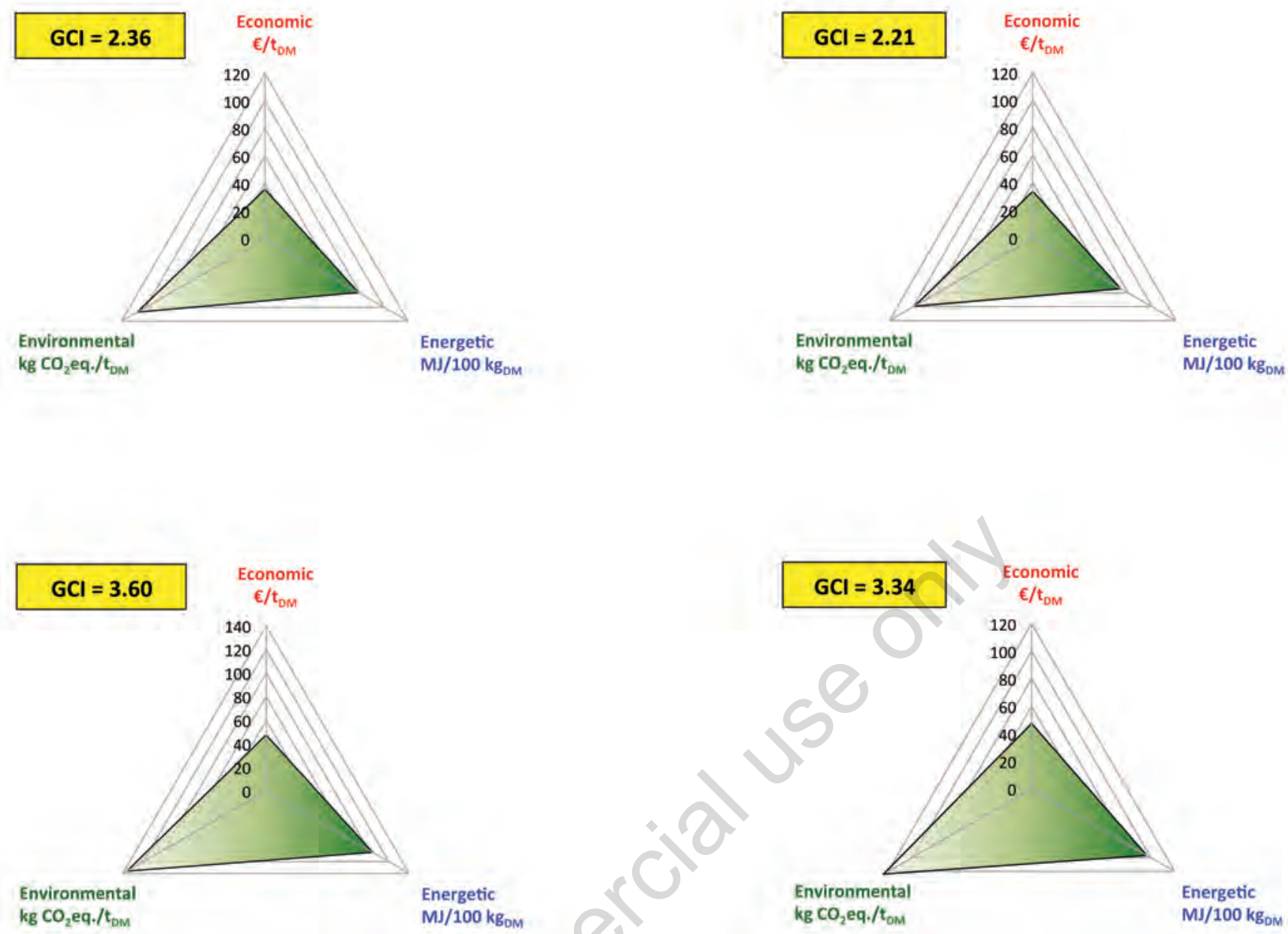

Figure 4. Economic, energy and environmental costs and global costs index (GCI) for the cases analyzed (poplar short rotation coppice area $=40 \mathrm{ha})$.

on specific costs, Figure 3 shows that, increasing the farm AUA $A_{\mathrm{ENERGY}}$ from 5 to 95 hectares, the IF application cause a non-negligible rise for both:

- energy cost: i) $+5.3 \div 6.8 \%$; and ii) $+6.4 \div 8.1 \%$, for the $\mathrm{H}$ and $\mathrm{L}$ cropping systems, respectively;

- environmental cost: i) $+6.2 \div 8.1 \%$; and (ii) $7.9 \div 10.0 \%$, for the $\mathrm{H}$ and $\mathrm{L}$ cropping systems, respectively. Taking $\mathrm{AUA}_{\mathrm{ENERGY}}$ as functional unit, the specific economic cost is higher for the $\mathrm{H}$ cropping system (range $571-558 € / \mathrm{ha}$, at 5 and $95 \mathrm{ha}$, respectively) compared with the L cropping system (range 424-432 €/ha). Nevertheless, also considering the economical returns, the $\mathrm{H}$ cropping system (due to the higher biomass yield) is more profitable than the L system. In fact, at a wood chip sale price of $30 € / \mathrm{t}_{\mathrm{WB}}$, the profit ranges: i) from $30.4 € / \mathrm{t}_{\mathrm{DM}}$ (at $\mathrm{AUA} \mathrm{ANERGY}_{\mathrm{EN}}=5 \mathrm{ha}$ ) to 31.3 (at $\mathrm{AUA} \mathrm{AN}_{\mathrm{EN}}$ ERGY $=95 \mathrm{ha}$ ); and ii) from 18.7 to $19.6 € / \mathrm{t}_{2}$, for the $\mathrm{H}$ and $\mathrm{L}$ cropping systems, respectively. Finally, assuming average farm management (e.g. $\left.\mathrm{AUA}_{\mathrm{ENERGY}}=40 \mathrm{ha}\right)$, Figure 4 shows for each case $(\mathrm{L}$, $\mathrm{L}+, \mathrm{H}-$ and $\mathrm{H}+$ ) the EEE costs and corresponding $\mathrm{GCI}$; the better values (lower triangle area, $\mathrm{GCI}=2.20$ and $\mathrm{GCI}=2.36$ ) are found with the $\mathrm{H}$ cropping system.

\section{Conclusions}

The need to increase energy production from renewable sources and to reduce the use of fossil fuels (the main cause of global warming) could result in the spread of AEC that are not fully sustainable from an economic, energy or environmental point of view. In the past, several software programs were developed to calculate the production costs of many processes. However, the great variability in the AGCs most commonly used in Europe together with the lack of both local information and specific parameters makes their application difficult. New software $\left(\mathrm{SE}^{3} \mathrm{~A}\right)$ has, therefore, been developed to evaluate the AGC performances and sustainability. The $\mathrm{SE}^{3} \mathrm{~A}$ helps to compare different chains or different technical solutions, and also computes the effect of the indirect production factors.

Although for the moment the analysis is limited to the first and second steps of the chain (field and post-harvest phases), $\mathrm{SE}^{3} \mathrm{~A}$ is already a useful tool for operators interested in agroenergy production. Its use in the near future with the post-harvest and conversion phases will allow the whole chain to be evaluated, defining its EEE specific costs 
per unit of energy produced ( $€ / \mathrm{kWh}, \mathrm{MJ} / \mathrm{kWh}, \mathrm{kg} \mathrm{CO}_{2} \mathrm{eq} / \mathrm{kWh}$ ) as well as its costs/benefits ratio.

The case study presented here refers to the energy poplar chain adopted in the Po valley by means of SRC plantations with two different cropping systems. The first cropping system $(\mathrm{H})$, is more intensive and aimed at achieving a high yield, while the second (L) is characterized by a lower input and a smaller biomass yield. For both the cropping systems, the computation of the EEE performances (economic, energy, environmental) is made by taking into account the energy and environmental costs of direct and indirect production factors. The selection of the functional unit plays an important role in the definition of the sustainability of the AEC. The specific economic cost depends on the share of farm AUA converted to SRC and, under the assumed conditions, it ranges between 36.2 and $48.0 € / \mathrm{t}_{\mathrm{DM}}$, respectively, for the $\mathrm{H}$ and $\mathrm{L}$ cropping systems. Economic profits are always greater for the $\mathrm{H}$ system due to the higher biomass yield. These profits do not take into account the land benefit, the farm management costs and public subsidies for biofuel production. Also, from the energy and environmental points of view, the best results are found with the $\mathrm{H}$ cropping system: the energy cost $\left(\mathrm{MJ} / \mathrm{t}_{\mathrm{DM}}\right)$ ranges from $4.2 \%$ to $5.7 \%$ of the wood chip Lower Heating Value.

IF have an effect on energy and environmental costs which is not negligible, reaching $10 \%$ of the total.

\section{Symbology}

AEC Agro-energy chains

DF Direct production factor

IF Indirect production factor

FU Functional unit

GER Gross energy requirement

GHG Greenhouses gases

GSI Global cost index

GWP Global warming potential

EEE Economic, energy and environmental

IPCC Intergovernmental panel on climate change

LCA Life cycle assessment

$P \quad$ AEC main product

B AEC byproduct

C AEC co-product

RE Renewable energy

$\mathrm{SE}^{3} \mathrm{~A} \quad$ Software for economic, energetic and environmental analysis

SRC Short rotation coppice

\section{References}

AA VV, 2006. The greenhouse gas calculation methodology for biomassbased electricity, heat and fuels. Report from Working group CO2 Methodology, pp 1-44.

ARGONNE, 2007. National Laboratory, U.S. Dept. of Energy, The Greenhouse Gases, Regulated Emissions, and Energy Use in Transportation (GREET) Model.

Bacenetti J, Fiala M, 2011. Short Rotation Coppice in Italy: a model to asses economic, energetic and environmental performances of different crop systems, 2011 World Renewable Energy Congr., Linköping, Sweden.

Bini G, Magistro S, 2002. Manuale dei fattori di emissione nazionali, Centro Tematico Nazionale Atmosfera Clima ed Emissioni Aria, Bozza Rapporto 1:1-193.

Cherubini F, 2009. Energy and greenhouse gas-based LCA of biofuel and bioenergy systems: key issues, ranges and recommendations. Resources, Conservation and Recycling 53:434-447.

D’Avino L, Lazzeri L, Dainelli R, Spugnoli P, 2010. Un software per la valutazione di sostenibilità delle filiere agro-energetiche Convegno Nazionale $\mathrm{IV}^{\circ}$ Sezione AIIA "Attualità della ricerca nel settore delle energie rinnovabili da biomassa", Ancona, Italy.

Daviet F, 2007. Designed a customized Green House Calculation Tool, The green house Protocol. World Resource Institute, pp 1-44.

Dubuisson X, Sintzo I, 1998. Energy and CO2-balances in different power generation routes using wood fuel from short rotation coppice. Biomass. Bioenerg. 15:379-90.

ERG, 2006. Energy and Resources Group Biofuel Analysis Meta-Model (EBAMM).

European Parliament and Council, 2009. Directive on the promotion of the use of energy from renewable sources, 2009/28/EC. In: Official Journal, vol. 283/33.

European Parliament and Council, 2010. Report from the Commission to the Council and the European Parliament on sustainability requirements for the use of solid and gaseous biomass sources in electricity, heating and cooling. Brussels, Belgium.

Farrell A, 2006. Ethanol can contribute to energy and environmental goals. Science 311:506-508

Fiala M, Bacenetti J, 2010a. Filiere agro-energetiche: costi economici, energetici e ambientali a bocca impianto. Convegno Nazionale 4th Sezione AIIA "Attualità della ricerca nel settore delle energie rinnovabili da biomassa", Ancona, Italy.

Fiala M, Bacenetti J, Scaravonati A, Bergonzi A, 2010b. Short rotation coppice in northern Italy: comprehensive sustainability. 18th European Biomass Conference, Lyon, France.

Fiala M, Bacenetti J, 2011. Economic, energetic and environmental impact in short rotation coppice harvesting operations. Biomass Bioenerg. (In Press.)

Fiorense G, Guariso G, Lazzarin A, Razzano R, 2007. Energia e nuove colture agricole, Polipress, pp 1-252.

Foppa Pedretti E, Riva G, Toscano G, Duca D, 2010. Considerations on renewable energy sources and their related perspectives of agricultural engineering, J. Agric. Eng. 2:35-45.

Franzese P, 2009. Sustainable biomass production: a comparison between Gross Energy Requirement and Energy Synthesis methods, Ecological Indicators, pp 959-970.

Gonzales S, Bacenetti J, Murphy R, Fiala M, 2010. Present and future environmental impact of poplar cultivation in Po valley (Italy) under different crop management systems. J Clean Prod 26:56-66.

Gasol CM, Gabarell X, Anton A, Rigola M, Carrasco J, Ciria P, Rieradevall J, 2009. Feasibility assessment of poplar bionergy systems in the Southern Europe. Renew Sustain Energy Rev. 13:801-812.

Guinée JB, (ed.) 2002. Handbook on Life Cycle Assessment, Operational Guide to the ISO Standards, pp 1-708.

Heller T, 2003. Life Cycle Assessment of a willow bioenergy cropping system. Biomass Bioenerg. 25:147-165.

Heller M, Keoleian G, Mann M, Volk T, 2004. Life cycle energy and environmental benefits of generating electricity from willow biomass. Renew. Energ. 29:1023-1042.

IPCC, 2006. Agriculture, Forestry and Other Land Use. In: Eggleston et al., IPCC Guidelines for National Greenhouse Gas Inventories, Prepared by the National Greenhouse Gas Inventories Programme.

ISO, 2006. Environmental management-Life Cycle AssessmentPrinciples and framework (ISO 14040). European Committee for Standardization, Brussels, Belgium.

Jarach M, 1985. Sui valori di equivalenza per l'analisi e il bilancio energetici in agricoltura. Rivista di Ingegneria Agraria 2;102-114.

Lai R, 2004. Carbon emission from farm operations. Environ. Int. 30:981-990.

Lazzari M, Mazzetto F, 2005. Prontuario di meccanica agraria e mecca- 
nizzazione, Edizioni Reda, pp 1-222.

Matthews R, 2001. Modelling of energy and carbon budgets of wood fuel coppice systems. Biomass. Bioenerg. 21:1-19.

Pimentel D, 2003. Ethanol fuels: Energy balance, economic and environmental impacts are negative. Nat. Resour. Res. 12;127-134.

Reap J, 2008a. A survey of unresolved problems in Life Cycle Assessment Part 1: goal and scope and inventory analysis. Int. J. Life Cycle Ass. 13:290-300.

Reap J, 2008b. A survey of unresolved problems in Life Cycle Assessment Part 2: impact assessment and interpretation. Int. J. Life Cycle Ass. 13:374-388.

Saunders C, Barber A, Taylor G, 2006. Food Miles - Comparative energy/emissions performance of New Zealand's agriculture industry.
Agribusiness and Economics Research Unit, Lincoln University, New Zealand, Research Report no. 285.

Shapouri H, Duffield J, Wang M, 2003. The energy balance of corn ethanol: an update, U.S. Department of Agriculture, Office of the Chief Economist, Office of Energy Policy and New Uses, Agricultural Economic Report no. 813.

Slesser M, Wallece I, 1982. Energy consumption per tonne of competing agricultural products available to the EC. In: Commission of the European Communities (ed.) Information on Agriculture 85:1-168.

Spugnoli P, Baldi F, Parenti A, 2009. An LCA model to assess the energy environmental improvement of new farming systems. J Agric Eng 4:19-25. 